MEDIKA ALKHAIRAAT : JURNAL PENELITIAN KEDOKTERAN DAN KESEHATAN 3(3): 109-116

e-ISSN: 2656-7822, p-ISSN: 2657-179X

\title{
TINGKAT PENGETAHUAN REMAJA TENTANG HIV/AIDS DI SMA NEGERI 4 PALU
}

\author{
Indriani Saputri ${ }^{1}$, Nita Damayanti ${ }^{*}$, Sakina Abdullah ${ }^{1}$ \\ ${ }^{1}$ Program Studi Pendidikan Dokter, Fakultas Kedokteran Universitas Alkhairat, Jl. Diponegoro No. 39 \\ Palu 94221, Sulawesi Tengah, Indonesia \\ *Corresponding author: Telp: +62 82292060496, email: nita.unisa@gmail.com
}

\begin{abstract}
ABSTRAK
HIV (Human Immunodeficiency Virus) adalah virus yang melemahkan system kekebalan tubuh. Secara global, sekitar 38 juta orang yang hidup dengan HIV pada akhir 2019. Jumlah kumulatif kasus terbanyak pada Afrika Selatan dan Afrika Timur sekitar 25,7 juta orang, sementara di Asia dan Pasifik sekitar 3,7 juta orang, amerika 3,7 juta orang, eropa 2,5 juta orang dan western pasifik 1,9 juta orang dengan HIV/AIDS. Total penderita HIV/AIDS dikota palu tahun 2007 hingga tahun 2016 sebanyak 523 orang, dengan 237 orang dinyatakan positif AIDS dan 91 orang diantaranya telah meninggal. Penelitian bertujua untuk mengetahui tingkat pengetahuan remaja tentang HIV/AIDS di SMA Negeri 4 Palu. Penelitian ini menggunakan desain penelitian deskriptif kuantitatif dengan pendekatan cross-sectional terhadap 89 siswa (i) di SMA Negeri 4 PALU pada tahun 2020 yang bertujuan untuk mengidentifikasi tingkat pengetahuan remaja tentang HIV/AIDS di SMA Negeri 4 PALU. Pengumpulan data dilakukan dengan wawancara menggunakan kuesioner onlineyang telah dibagikan oleh peneliti melalui link google form. Analisa data menggunakan SPSS 24 dengan uji frekuensi. Hasil penelitian menunjukkan tingkat pengetahuan Remaja tentang HIV/AIDS di SMA Negeri 4 Palu didapatkan hasil tingkat pengetahuan cukup yaitu sebanyak 44 orang $(49,4 \%)$, kemudian disusul dengan pengetahuan baik yaitu sebanyak 29 orang $(32,6 \%)$ dan pengetahuan kurang yaitu sebanyak 16 orang $(18,0)$. (2) Tingkat pengetahuan remaja tentang Pengertian dan Penyebab HIV di SMA Negeri 4 Palu yang paling banyak diraih oleh kategori Baik yaitu sebanyak 47 orang $(52,8 \%)$, kemudian disusul dengan tingkat pengetahuan kategori Cukup sebanyak 27 orang $(30,3 \%)$ dan yang paling sedikit yaitu tingkat pengetahuan kategori Kurang sebanyak 15 orang (16,9\%). (3) Tingkat pengetahuan remaja tentang cara penularan HIV/AIDS di SMA Negeri 4 Palu tahun 2021 yang paling banyak diraih oleh kategori cukup yaitu sebanyak 39 orang $(43,8 \%)$, kemudian disusul dengan tingkat pengetahuan kategori baik sebanyak 31 orang $(34,8 \%)$ dan yang paling sedikit yaitu ti ngkat pengetahuan kategori kurang sebanyak 19 orang (21,3\%).(4) Tingkat pengetahuan remaja tentang Gejala HIV/AIDS di SMA Negeri 4 Palu tahun 2021 yang paling banyak diraih oleh kategori cukup yaitu sebanyak 38 orang (42,7\%), kemudian disusul dengan tingkat pengetahuan kategori kurang sebanyak 27 orang (30,3\%) dan yang paling sedikit yaitu tingkat pengetahuan kategori baik sebanyak 24 orang $(27,0 \%)$.(5) tingkat pengetahuan remaja tentang pengendalian dan pencegahan HIV/AIDS di SMA Negeri 4 Palu tahun 2021 yang paling banyak diraih oleh kategori cukup yaitu sebanyak 35 orang $(39,3 \%)$, kemudian disusul dengan tingkat pengetahuan kategori baik sebanyak 32 orang $(36,0 \%)$ dan yang paling sedikit yaitu tingkat pengetahuan kategori kurang sebanyak 22 orang (24,7\%). Disimpulkan bahwa tingkat pengetahuan Remaja tentang HIV/AIDS di SMA Negeri 4 Palu didapatkan hasil tingkat pengetahuan cukup.
\end{abstract}

Kata Kunci: Tingkat pengetahuan, Human Immunodeficiency Virus, SMAN 4 Palu

\section{ABSTRACT}

HIV (Human Immunodeficiency Virus) is a virus that weakens the immune system. Globally, about 38 million people were living with HIV at the end of 2019. The cumulative number of cases was highest in South Africa and East Africa about 25.7 million people, while in Asia and the Pacific around 3.7 million people, America 3.7 million people, Europe 2.5 million people 
MEDIKA ALKHAIRAAT : JURNAL PENELITIAN KEDOKTERAN DAN KESEHATAN 3(3):109-116 e-ISSN: 2656-7822, p-ISSN: 2657-179X

and the Western Pacific 1.9 million people with HIV/AIDS. The total number of HIV/AIDS sufferers in Palu from 2007 to 2016 was 523 people, of which 237 people were tested positive for AIDS and 91 of them had died. This study aims to determine the level of knowledge of adolescents about HIV/AIDS in SMA Negeri 4 Palu. This study uses a quantitative descriptive research design with a cross-sectional approach to 89 students (i) at SMA Negeri 4 PALU in 2020 which aims to identify the level of knowledge of adolescents about HIV/AIDS in SMA Negeri 4 PALU. Data was collected by interview using an online questionnaire that had been distributed by the researcher via the google form link. Data analysis using SPSS 24 with a frequency test. The results showed that the level of knowledge of adolescents about HIV/AIDS in SMA Negeri 4 Palu showed that the level of knowledge was sufficient, namely 44 people (49.4\%), followed by good knowledge, namely 29 people (32.6\%) and lack of knowledge, namely as many as 16 people $(18,0)$. (2) The level of knowledge of adolescents about the Definition and Causes of HIV in SMA Negeri 4 Palu was mostly achieved by the Good category, namely 47 people (52.8\%), followed by the level of knowledge in the Enough category as many as 27 people $(30.3 \%)$ and the least is the level of knowledge in the Less category as many as 15 people (16.9\%). (3) The level of adolescent knowledge about how to transmit HIV/AIDS at SMA Negeri 4 PALU in 2021 was the most achieved by the moderate category, namely 39 people (43.8\%), followed by the level of knowledge in the good category as many as 31 people $(34,8 \%)$ and the least is the level of knowledge in the less category as many as 19 people (21.3\%).(4) The level of knowledge of adolescents about HIV/AIDS symptoms at SMA Negeri 4 Palu in 2021 was achieved the most by the moderate category, which was as much as 38 people (42.7\%), followed by the level of knowledge in the poor category as many as 27 people (30.3\%) and the least, namely the level of knowledge in the good category as many as 24 people (27.0\%).(5) the level of knowledge of adolescents on control and prevention of HIV/AIDS in SMA Negeri 4 Palu in 2021, which was mostly achieved by the moderate category, which was 35 people (39.3\%), then followed by the level of knowledge in the good category as many as 32 people (36.0\%) and those in the good category. the least is the level t lack of knowledge category as many as 22 people (24,7\%). It was concluded that the level of knowledge of adolescents about HIVIAIDS in SMA Negeri 4 PALU resulted in a sufficient level of knowledge.

Keywords: Knowledge, Human Immunodeficiency Virus, SMAN 4 Palu

\section{PENDAHULUAN}

Sejak ditemukan kasus AIDS pertama kali di Amerika Serikat (AS) pada tahun 1981 hingga sekarang selalu menarik perhatian dunia kedokteran maupun masyarakat luas. Hal ini karena angka kematiannya yang tinggi dan jumlah penderita yang meningkat dalam waktu singkat. Sejak itu pula penelitian mengenai AIDS dan virus HIV berkembang dengan sangat pesat. ${ }^{1}$

Secara global, sekitar 38 juta orang yang hidupdengan HIV pada akhir 2019. Jumlah kumulatif kasus terbanyak pada Afrika Selatan dan Afrika Timur sekitar 25,7 juta orang, sementara di Asia dan Pasifik sekitar 3,7 juta orang, amerika 3,7 juta orang, eropa 2,5 juta orang dan western pasifik 1,9 juta orang dengan HIV/AIDS. ${ }^{2}$

Perkembangan kasus HIV/AIDS di Indonesia mengalami peningkatan hingga desember 2017 sebanyak 280.623 orang terinfeksi HIV dan sebanyak 102.667 orang menderita AIDS yang tersebar di 421 dari 514 kabupaten/kota diseluruh provinsi di Indonesia. Provinsi pertama kalinya ditemukan adanya HIV/AIDS adalah provinsi bali. Jumlah infeksi HIV tertinggi yaitu DKI Jakarta (51.981), diikuti jawa timur (39.633), papua $(29.083)$, jawa barat $(28,964)$ dan jawa tengah (22.292) dan jumlah AIDS terbanyak dilaporkan dari papua $(19,729)$, jawa timur (18.243), DKI Jakarta (9.215), jawa tengah (8.170), bali jawa barat (6.502). ${ }^{3}$

Sementara total penderita HIV/AIDS dikota palu tahun 2007 hingga tahun 2016 sebanyak 523 orang, dengan 237 orang dinyatakan positif AIDS dan 91 orang diantaranya telah meninggal. ${ }^{4}$

Berdasarkan data dari dinas kesehatan kota palu presentase kasus HIV/AIDS menurut 
kelompok umur adalah sebagai berikut: 25-29 tahun (29\%), 30-34 tahun (20\%), 20-24 tahun (19\%), 35-39 tahun (15\%), 40-49 tahun (3\%), 0-14 tahun (2\%), dan $>50$ tahun $(2 \%){ }^{5}$

\section{METODOLOGI}

Penelitian menggunakan menggunakan desain penelitian deskriptif kuantitatif yang bertujuan untuk mengidentifikasi tingkat pengetahuan RemajaSMA tentang HIV/AIDS. Pendekatan yang digunakan dalam penelitian ini adalah pendekatan cross sectional yaitu suatu penelitian untuk mempelajari dinamika korelasi antara faktor-faktor resiko dengan efek melalui pendekatan, observasi, atau pengumpulan data sekaligus pada suatu saat (point time approach).

Artinya tiap subjek penelitian hanya diobservasi sekali saja dan pengukuran dilakukan pada saat penelitian, hal ini tidak berarti bahwa semua subjek penelitian diamati pada waktu yang sama.
Penelitian dilakukan pada bulan maret tahun 2021, bertempat di SMA Negeri 4 Palu. Adapun populasi dan subyek penelitian adalah siswa-siswi SMA NEGERI 4 Palu yang memenuhi kriteria penelitian yaitu sebanyak 89 orang. Teknik pengambilan sampel yang digunakan dalam pada penelitian ini adalah Proporsional Stratified Random Sampling.

\section{HASIL DAN PEMBAHASAN}

HASIL

\section{Karakteristik Responden}

Karakteristik sampel berdasarkan Jenis Kelamin, usia, kelas dan sumber informasi.

Untuk mengetahui hasil penelitian karakteristik Siswa (i) berdasarkan jenis kelamin, usia, kelas dan sumber informasi dapat dilihat pada Tabel 1 dibawah ini:

Tabel 1. Karakteristik Sampel Berdasarkan Jenis Kelamin, Usia, Kelas dan Sumber Informasi Tingkat Pengetahuan Remaja tentang HIV/AIDS

\begin{tabular}{|c|c|c|c|c|c|}
\hline Karakteristik & & Baik & Cukup & Kurang & Jumlah \\
\hline \multicolumn{6}{|l|}{ Jenis Kelamin } \\
\hline \multirow[t]{2}{*}{ Laki-Laki } & $\mathrm{n}$ & 3 & 10 & 8 & 21 \\
\hline & $\%$ & $14,3 \%$ & $47.6 \%$ & $38,1 \%$ & $100 \%$ \\
\hline \multirow[t]{2}{*}{ Perempuan } & $\mathrm{n}$ & 26 & 34 & 8 & 68 \\
\hline & $\%$ & $38.2 \%$ & $50.0 \%$ & $11.8 \%$ & $100 \%$ \\
\hline \multicolumn{6}{|l|}{ Usia } \\
\hline \multirow[t]{2}{*}{ 14-16 Tahun } & $\mathrm{n}$ & 22 & 35 & 10 & 67 \\
\hline & $\%$ & $32.8 \%$ & $52.2 \%$ & $14.9 \%$ & $100 \%$ \\
\hline \multirow[t]{2}{*}{ 17-20 Tahun } & $\mathrm{n}$ & 7 & 9 & 6 & 22 \\
\hline & $\%$ & $31.8 \%$ & $40.9 \%$ & $27.3 \%$ & $100 \%$ \\
\hline \multicolumn{6}{|l|}{ Kelas } \\
\hline \multirow[t]{2}{*}{1} & $\mathrm{n}$ & 10 & 26 & 8 & 44 \\
\hline & $\%$ & $22.7 \%$ & $59.1 \%$ & $18.2 \%$ & $100 \%$ \\
\hline \multirow[t]{2}{*}{2} & $\mathrm{n}$ & 19 & 18 & 8 & 45 \\
\hline & $\%$ & $42.2 \%$ & $40.0 \%$ & $17.8 \%$ & $100 \%$ \\
\hline \multicolumn{6}{|l|}{ Sumber Informasi } \\
\hline Media & $\mathrm{n}$ & 10 & 10 & 3 & 23 \\
\hline Cetak/Elektronik & $\%$ & $43.5 \%$ & $43.5 \%$ & $13.0 \%$ & $100 \%$ \\
\hline \multirow[t]{2}{*}{ Orang Lain } & $\mathrm{n}$ & 19 & 34 & 13 & 66 \\
\hline & $\%$ & $28.8 \%$ & $51.5 \%$ & $19.7 \%$ & $100 \%$ \\
\hline \multirow[t]{2}{*}{ Jumlah } & $\mathrm{n}$ & & & & 89 \\
\hline & $\%$ & & & & $100 \%$ \\
\hline
\end{tabular}


Berdasarkan tabel diatas menunjukkan bahwa berdasarkan karakteristik jenis kelamin didapatkan hasil sebagian besar remaja SMA Negeri 4 PALU Berjenis kelamin perempuan memiliki pengetahuan cukup sebanyak 34 orang $(50.0 \%)$. Berdasarkan karakteristik usia didapatkan hasil sebagian besar remaja SMA Negeri 4 PALU berusia 14-16 tahun memiliki pengetahuan cukup 35 orang $(52.2 \%)$. Berdasarkan karakteristik kelas didapatkan hasil sebagian besar remaja SMA Negeri 4 PALU kelas 1 memiliki pengetahuan cukup 26 orang $(59,1 \%)$. Berdasarkan Sumber informasi didapatkan sebagian besar remaja SMA Negeri 4 PALU mendapatkan sumber informasi dari orang lain memiliki pengetahuan cukup 34 orang $(51,5 \%)$.

\section{Tingkat Pengetahuan Remaja SMA}

Untuk mengetahui tingkat pengetahuan Remaja tentang HIV/AIDS di SMA Negeri 4 PALU terdapat pada tabel sebagai berikut.

\subsection{Tingkat Pengetahuan Remaja SMA tentang HIV/AIDS}

Untuk mengetahui hasil penelitian tingkat pengetahuan remaja tentang HIV/AIDS, dapat dilihat pada Tabel 2 dibawah ini.

Tabel 2. Tingkat Pengetahuan Remaja SMA tentang HIV/AIDS

\begin{tabular}{lll}
\hline $\begin{array}{l}\text { Tingkat Pengetahuan Remaja } \\
\text { tentang HIV/AIDS }\end{array}$ & $\mathrm{n}$ & $\%$ \\
\hline Baik & 29 & 32,6 \\
Cukup & 44 & 49,4 \\
Kurang & 16 & 18,0 \\
\hline Jumlah & 89 & 100 \\
\hline
\end{tabular}

Dari tabel diatas menunjukkan bahwa dari 89 sampel penelitian, diperoleh tingkat pengetahuan remaja tentang HIV/AIDS di SMA Negeri 4 Palu yang paling banyak diraih oleh kategori cukup yaitu sebanyak 44 orang $(49,4, \%)$, kemudian disusul dengan tingkat pengetahuan kategori baik sebanyak 29 orang $(32,6 \%)$ dan yang paling sedikit yaitu tingkat pengetahuan kategori Kurang sebanyak 16 orang $(18,0 \%)$.

2.2 Tingkat Pengetahuan Remaja SMA tentang Pengertian dan Penyebab HIV/AIDS
Untuk mengetahui hasil penelitian tingkat pengetahuan remaja tentang Pengertian dan Penyebab HIV, dapat dilihat pada Tabel 3 dibawah ini:

Tabel 3.Tingkat Pengetahuan Remaja SMA tentang Pengertian dan Penyebab HIV

\begin{tabular}{|c|c|c|}
\hline $\begin{array}{l}\text { Tingkat Pengetahuan Remaja } \\
\text { tentang Pengertian dan } \\
\text { Penyebab HIV/AIDS }\end{array}$ & $\mathrm{n}$ & $\%$ \\
\hline Baik & 47 & 52,8 \\
\hline Cukup & 27 & 30,3 \\
\hline Kurang & 15 & 16,9 \\
\hline Jumlah & 89 & 100 \\
\hline
\end{tabular}

Dari tabel diatas menunjukkan bahwa dari 89 sampel penelitian, diperoleh tingkat pengetahuan remaja tentang Pengertian dan Penyebab HIV di SMA Negeri 4 Palu yang paling banyak diraih oleh kategori Baik yaitu sebanyak 47 orang $(52,8 \%)$, kemudian disusul dengan tingkat pengetahuan kategori Cukup sebanyak 27 orang $(30,3 \%)$ dan yang paling sedikit yaitu tingkat pengetahuan kategori Kurang sebanyak 15 orang $(16,9 \%)$.

\subsection{Tingkat Pengetahuan Remaja SMA tentang Cara Penularan HIV/AIDS}

Untuk mengetahui hasil penelitian tingkat pengetahuan remaja tentang Cara Penularan HIV/AIDS, dapat dilihat pada Tabel 4 dibawah ini:

Tabel 4. Tingkat Pengetahuan Remaja tentang cara penularan HIV/AIDS

\begin{tabular}{|c|c|c|}
\hline $\begin{array}{l}\text { Tingkat Pengetahuan Remaja } \\
\text { tentang cara penularan } \\
\text { HIV/AIDS }\end{array}$ & $\mathrm{n}$ & $\%$ \\
\hline Baik & 31 & 34,8 \\
\hline Cukup & 39 & 43,8 \\
\hline Kurang & 19 & 21,3 \\
\hline Jumlah & 89 & 100 \\
\hline
\end{tabular}

Dari tabel diatas menunjukkan bahwa dari 89 sampel penelitian, diperoleh tingkat pengetahuan remaja tentang cara penullaran HIV/AIDS di SMA Negeri 4 PALU tahun 2021 yang paling banyak diraih oleh kategori cukup yaitu sebanyak 39 orang $(43,8 \%)$, kemudian disusul dengan tingkat pengetahuan kategori baik sebanyak 31 orang $(34,8 \%)$ dan yang paling sedikit yaitu ti ngkat pengetahuan kategori kurang sebanyak 19 orang $(21,3 \%)$. 
MEDIKA ALKHAIRAAT : JURNAL PENELITIAN KEDOKTERAN DAN KESEHATAN 3(3): 109-116

e-ISSN: 2656-7822, p-ISSN: 2657-179X

2.4 Tingkat Pengetahuan Remaja SMA tentang Gejala HIV/AIDS

Untuk mengetahui hasil penelitian tingkat pengetahuan Remaja tentang Gejala HIV/AIDS, dapat dilihat pada Tabel 5 dibawah ini:

Tabel 5. Tingkat Pengetahuan Remaja tentang Gejala HIV/AIDS

\begin{tabular}{lll}
\hline $\begin{array}{l}\text { Tingkat Pengetahuan Remaja } \\
\text { tentang Gejala HIV/AIDS }\end{array}$ & $\mathrm{n}$ & $\%$ \\
\hline Baik & 24 & 27,0 \\
Cukup & 38 & 42,7 \\
Kurang & 27 & 30,3 \\
\hline Jumlah & 89 & 100 \\
\hline
\end{tabular}

Dari tabel diatas menunjukkan bahwa dari 89 sampel penelitian, diperoleh tingkat pengetahuan remaja tentang Gejala HIV/AIDS di SMA Negeri 4 PALU tahun 2021 yang paling banyak diraih oleh kategori cukup yaitu sebanyak 38 orang $(42,7 \%)$, kemudian disusul dengan tingkat pengetahuan kategori kurang sebanyak 27 orang $(30,3 \%)$ dan yang paling sedikit yaitu tingkat pengetahuan kategori baik sebanyak 24 orang $(27,0 \%)$.

2.5 Tingkat Pengetahuan Remaja SMA tentang Pengendalian dan pencegahan HIV/AIDS

Untuk mengetahui hasil penelitian tingkat pengetahuan remaja tentang Pencegahan dan pengendalian HIV/AIDS, dapat dilihat pada Tabel 6 dibawah ini:

Tabel 6. Tingkat Pengetahuan Remaja tentang Pengendalian dan pencegahan HIV/AIDS.

\begin{tabular}{|c|c|c|}
\hline $\begin{array}{l}\text { Tingkat Pengetahuan Remaja } \\
\text { tentang Pengendalian dan } \\
\text { Pencegahan HIV/AIDS }\end{array}$ & $\mathrm{n}$ & $\%$ \\
\hline Baik & 24 & 27,0 \\
\hline Cukup & 38 & 42,7 \\
\hline Kurang & 27 & 30,3 \\
\hline Jumlah & 89 & 100 \\
\hline
\end{tabular}

Dari tabel diatas menunjukkan bahwa dari 89 sampel penelitian, diperoleh tingkat pengetahuan remaja tentang pengendalian dan pencegahan HIV/AIDS di SMA Negeri 4 PALU tahun 2021 yang paling banyak diraih oleh kategori cukup yaitu sebanyak 35 orang
(39,3\%), kemudian disusul dengan tingkat pengetahuan kategori baik sebanyak 32 orang $(36,0 \%)$ dan yang paling sedikit yaitu tingkat pengetahuan kategori kurang sebanyak 22 orang $(24,7 \%)$.

\section{PEMBAHASAN}

\section{Tingkat Pengetahuan Remaja SMA tentang} HIV/AIDS di SMAN 4 PALU

Berdasarkan hasil diketahui, bahwa tingkat pengetahuan remaja tentang HIV di SMA Negeri 4 Palu yang paling banyak diraih oleh kategori cukup yaitu sebanyak 44 orang $(49,4, \%)$, kemudian disusul dengan tingkat pengetahuan kategori baik sebanyak 29 orang $(32,6 \%)$ dan yang paling sedikit yaitu tingkat pengetahuan kategori Kurang sebanyak 16 orang $(18,0 \%)$.

Hasil tersebut tidak sejalan dengan penelitian yang dilakukan oleh Abihud L Sawaki (2017) yang menemukan dalam penelitiannya terkait dengan pengetahuan di SMP dan SMA di wamena papua 2017 yaitu kebanyakan dari responden penelitiannya memiliki tingkat pengetahuan kategori baik 83 orang $(95,4 \%)$ sementara responden dengan tingkat pengetahuan kategori cukup yaitu 4 orang $(4,6 \%)$. Hal tersebut didapatkan oleh karena dipengaruhi oleh faktor responden yang masih berada pada bangku sekolah atau dengan status sebagai pelajar SMP dan SMA. Dimana mereka masih mendapatkan informasi dan edukasi tentang penyakit HIV/AIDS, mereka juga masih terpapar dengan ajaran tentang bahaya dan juga cara pencegahan dari penyakit HIV/AIDS. ${ }^{6}$

Namun pada penelitian lain yang dilakukan oleh Linda Citra Wardani (2017) di Yogyakarta menemukan hal yang senada dengan penelitian ini, dimana responden pada penelitiannya ditemukan dominan tingkat pengetahuan Remaja dalam kategori sedang yaitu cukup yaitu sebanyak $28(62,2 \%)$. Hal tersebut didapatkan oleh karena responden belum pernah mendapatkan informasi kesehatan mengenai HIV/AIDS seperti penyuluhan tentang HIV/AIDS. Dan sebagian besar responden memperoleh informasi mengenai HIV/AIDS dari orang lain. ${ }^{7}$

Berdasarkan hasil penelitian ini dapat disimpulkan bahwa tingkat pengetahuan remaja tentang HIV/AIDS di SMA Negeri 4 
Palu dalam kategori cukup. Hal ini didukung karena remaja di SMAN 4 PALU tidak semua mengetahui pengertian dan penyebab HIV/AIDS dan sebagian besar siswa mendapatkan informasi tentang HIV/AIDS dari orang lain.

\section{Tingkat Pengetahuan Remaja SMA tentang Pengertian dan Penyebab HIV/AIDS di SMAN 4 PALU}

Berdasarkan hasil diketahui, bahwa tingkat pengetahuan remaja tentang Pengertian dan Penyebab HIV di SMA Negeri 4 Palu yang paling banyak diraih oleh kategori Baik yaitu sebanyak 47 orang $(52,8 \%)$, kemudian disusul dengan tingkat pengetahuan kategori Cukup sebanyak 27 orang $(30,3 \%)$ dan yang paling sedikit yaitu tingkat pengetahuan kategori Kurang sebanyak 15 orang (16,9\%).

Penelitian ini sejalan dengan penelitian yang dilakukan Fafi Rahmati (2014) dengan hasil tingkat pengetahuan tentang pengertian dan penyebab HIV/AIDS dalam kategori baik yaitu (96\%). Hal ini dapat disebabkan karena sebaran responden berdasarkan tingkat pengetahuan HIV/AIDS sangat bervariasi oleh jawaban responden yang juga bervariasi. ${ }^{8}$

Berdasarkan hasil penelitian ini dapat disimpulkan bahwa tingkat pengetahuan remaja tentang Pengertian dan Penyebab HIV di SMA Negeri 4 Palu yang paling banyak diraih oleh kategori Baik. Pengetahuan yang baik tentang pengertian dan penyebab HIV/AIDS menunjukkan bahwa Remaja di SMAN 4 PALU sudah banyak yang tahu dan paham tentang pengertian dan penyebab HIV/AIDS.

\section{Tingkat Pengetahuan Remaja SMA tentang Cara Penularan HIV/AIDS di SMAN 4 PALU}

Berdasarkan hasil diketahui, bahwa tingkat pengetahuan Remaja tentang cara penullaran HIV/AIDS di SMA Negeri 4 PALU tahun 2021 yang paling banyak diraih oleh kategori cukup yaitu sebanyak 39 orang (43,8\%), kemudian disusul dengan tingkat pengetahuan kategori baik sebanyak 31 orang $(34,8 \%)$ dan yang paling sedikit yaitu tingkat pengetahuan kategori kurang sebanyak 19 orang $(21,3 \%)$.

Penelitian ini sejalan dengan penelitian yang dilakukan Nastiti Insani (2016) dengan hasil tingkat pengetahuan tentang cara penularan HIV/ADS yang dilakukan di SMK Muhammadiyah Yogyakarta pada kelas XI adalah cukup. Hal ini dapat disebabkan karena responden sebagian besar mendapatkan informasi tentang cara penularan dari orang lain. $^{9}$

Berdasarkan hasil penelitian ini dapat disimpulkan bahwa tingkat pengetahuan remaja tentang cara penularan HIV/AIDS di SMA Negeri 4 PALU tahun 2021 yang paling banyak diraih oleh kategori cukup. Hal ini didukung karena remaja di SMAN 4 PALU tidak semua mengetahui cara penularan HIV/AIDS dan sebagian besar siswa mendapatkan informasi tentang HIV/AIDS dari orang lain.

\section{Tingkat Pengetahuan Remaja SMA tentang Gejala HIV/AIDS di SMAN 4 PALU}

Berdasarkan hasil diketahui, bahwa tingkat pengetahuan remaja tentang Gejala HIV/AIDS di SMA Negeri 4 PALU tahun 2021 yang paling banyak diraih oleh kategori cukup yaitu sebanyak 38 orang $(42,7 \%)$, kemudian disusul dengan tingkat pengetahuan kategori kurang sebanyak 27 orang $(30,3 \%)$ dan yang paling sedikit yaitu tingkat pengetahuan kategori baik sebanyak 24 orang $(27,0 \%)$.

Penelitian ini tidak sejalan dengan penelitian yang dlakukan Nastiti (2016) dengan hasil tingkat pengetahuan tentang gejala HIV/AIDS Yang dilakuka di SMK Muhammadiyyah YOGYAKARTA adalah baik dikarenakan sumber informasi yang mereka peroleh sebagian besar dari media cetak/elektronik. ${ }^{9}$

Berdasarkan hasil penelitian ini dapat disimpulkan bahwa tingkat pengetahuan remaja tentang Gejala HIV/AIDS di SMA Negeri 4 PALU tahun 2021 yang paling banyak diraih oleh kategori cukup. Hal ini di karenakan remaja di SMAN 4 PALU tidak semua mengetahui gejala HIV/AIDS dan sebagian besar siswa mendapatkan informasi tentang HIV/AIDS dari orang lain.

\section{Tingkat Pengetahuan Remaja SMA tentang Pengendalian dan Pencegahan di SMAN 4 PALU}

Berdasarkan hasil diketahui, bahwa tingkat pengetahuan remaja tentang pengendalian dan 
pencegahan HIV/AIDS di SMA Negeri 4 PALU tahun 2021 yang paling banyak diraih oleh kategori cukup yaitu sebanyak 35 orang (39,3\%), kemudian disusul dengan tingkat pengetahuan kategori baik sebanyak 32 orang $(36,0 \%)$ dan yang paling sedikit yaitu tingkat pengetahuan kategori kurang sebanyak 22 orang $(24,7 \%)$.

Penelitian ini sejalan dengan penelitian yang dilakukan oleh Yowel Kambu (2012) dengan hasil sebagian besar responden (73.3\%) termasuk dalam kategori cukup dalam pencegahan HIV/AIDS. Hal ini disebabkan karena sebagian respon mendapatkan informasi mengenai pengendalian dan pencegahan HIV/AIDS dari orang lain. ${ }^{10}$

Berdasarkan hasil penelitian ini dapat disimpulkan bahwa tingkat pengetahuan remaja tentang pengendalian dan pencegahan HIV/AIDS di SMA Negeri 4 PALU tahun 2021 yang paling banyak diraih oleh kategori cukup. Hal ini disebabkan karena sebagian respon mendapatkan informasi mengenai pengendalian dan pencegahan HIV/AIDS dari orang lain dan masih ada beberapa siswa yang masih kurang paham mengenai cara pencegahan dan pengedalian HIV/AIDS.

\section{KESIMPULAN DAN SARAN}

Berdasarkan hasil penelitian dari 89 Remaja tentang HIV/AIDS di SMA Negeri 4 PALU didapatkan kesimpulan sebagai berikut:

1. Tingkat pengetahuan Remaja tentang HIV/AIDS di SMA Negeri 4 PALU didapatkan hasil tingkat pengetahuan cukup yaitu sebanyak 44 orang $(49,4 \%)$, pengetahuan baik yaitu sebanyak 29 orang $(32,6 \%)$ dan pengetahuan kurang yaitu sebanyak 16 orang $(18,0 \%)$.

2. Tingkat pengetahuan Remaja tentang Penyebab HIV/AIDS di SMA Negeri 4 PALU didapatkan hasil tingkat pengetahuan Baik yaitu sebanyak 47 orang $(52,8 \%)$, pengetahuan cukup yaitu sebanyak 27 orang $(30,3 \%)$ dan pengetahuan kurang yaitu sebanyak 15 orang $(16,9 \%)$.

3. Tingkat pengetahuan Remaja tentang Cara Penularan HIV/AIDS di SMA Negeri 4 PALU didapatkan hasil tingkat pengetahuan cukup yaitu sebanyak 39 orang $(43,8 \%)$, pengetahuan baik yaitu sebanyak 31 orang $(34,8 \%)$ dan pengetahuan kurang yaitu sebanyak 19 orang $(21,3 \%)$.

4. Tingkat pengetahuan Remaja tentang Gejala HIV/AIDS di SMA Negeri 4 PALU didapatkan hasil tingkat pengetahuan cukup yaitu sebanyak 38 orang (42.7\%), pengetahuan baik yaitu sebanyak 24 orang $(27.0 \%)$ dan pengetahuan kurang yaitu 27 orang $(30,3 \%)$.

5. Tingkat pengetahuan Remaja tentang Pengendalian dan Pencegahan HIV/AIDS di SMA Negeri 4 PALU didapatkan hasil tingkat pengetahuan cukup yaitu sebanyak 35 orang $(39,3 \%)$, pengetahuan baik yaitu 32 orang $(36,0 \%)$ dan pengetahuan kurang yaitu 22 orang $(24.7 \%)$.

Sebagai saran penulis agar pada penelitian selanjutnya, Peneliti selanjutnya diharapkan dapat mengembangkan hasil penelitian ini dari satu variable dan dikembangan menjadi dua variable.

\section{DAFTAR PUSTAKA}

1. Daili Fahmi Sjaiful, Zubier Farida. Ilmu Penyakit Kulit dan Kelamin. Edisi 7. Jakarta: 2018 Hal.490

2. World Health Organization. Fact Sheet HIV/AIDS. 06 July 2020.https://www.who.int/news-room/factsheets/detail/hiv-aids . di akses pada tanggal 03 agustus 2020

3. Mubarok. 2007. Promosi Kesehatan Sebuah Pengantar Proses belajar Mengajar Dalam Pendidikan. Yogyakarta. Graha Ilmu

4. Dinas Kesehatan Kota Palu Tahun 2016. Palu; 2016.

5. Dinas Kesehatan Kota Palu. Profil Kesehatan Kota Palu Tahun 2017. Palu; 2017

6. Abihud L Sawaki. Pengetahuan Remaja tentang HIV/AIDS di SMP dan SMA di Wamena Papua. 2017

7. Linda Citra Wardani. Gambaran Tingkat Pengetahuan Remaja tentang HIV/AIDS di MA Muhammad Gedongtengen Yogyakarta. 2017

8. Rachmati, Fafi. Hubungan Tingkat Pengetahuan tentang HIV/AIDS dengan 
MEDIKA ALKHAIRAAT : JURNAL PENELITIAN KEDOKTERAN DAN KESEHATAN 3(3):109-116

e-ISSN: 2656-7822, p-ISSN: 2657-179X

Sikap Terhadap Pencegahannya pada Siswa

Kelas X dan XI di SMA Taman Madya Jetis Yogyakarta. 2014

9. Insani Nastiti. Tingkat Pengetahuan Remaja tentang HIV/AIDS pada Siswa Kelas XI dan XII di SMK Muhammadiyah 4 Yogyakarta. 2016

10. Kambu Yowel. Analisis Faktor-Faktor yang Mempengaruhi Tindakan Pencegahan Penularan HIV oleh Odha di Sorong. Skripsi Universitas Indonesia. 2012 